\title{
Genetically Modified Foods and the Probable Risks on Human Health
}

\author{
Gulcin Algan Ozkok \\ Vocational School of Health Sciences Child Development Program, Selcuk University, Campus, Konya, Turkey
}

\section{Email address:}

gulcin8751@hotmail.com

\section{To cite this article:}

Gulcin Algan Ozkok. Genetically Modified Foods and the Probable Risks on Human Health. International Journal of Nutrition and Food Sciences. Vol. 4, No. 3, 2015, pp. 356-363. doi: 10.11648/j.ijnfs.20150403.23

\begin{abstract}
Changing existing features of living beings or giving new features to them by changing the natural gene sequence through biotechnological methods is called "genetically modified organisms", in short "GMO". Nowadays, lots of food consumed is either totally genetically modified food or a type of food including food components produced by gene modification technology. Improving nutritive quality, extracting aminoacids as food additives and enzymes in microorganisms, increasing retention period and organeolepticquality, new planting methods, precocity, resistance against disease, stres, herbicide and viruses, better waste utilization, saving of soil, water and energy, creating new bioprocesses are the probable advantages of genetically modified organisms, whereas changes in food quality, genetic diversity threats, unfair competition between organic suppliers and traditional suppliers, noncompulsory awarness raising in some countries, food industry dominated only by a few big companies, biopiracy and consuming of natural resources by foreigners are among the probable disadvantages of genetically modified foods. Among the hesitations about GMO widely used and consumed all over the world, the most topical issue is the probable health risks caused by GMOs which are consumed as food. Through gene transfer, some features causing allergy and disease can be carried from other organism and as a consequence of this, there may be the risk of finding unexpected biochemical products in transgenic products. As uncertainities about GM foods continue, studies conducted in many countries have revealed that there are many differences among people's information, attitude and behaviour toward this issue in various countries. Modified food is affected by factors such as education and knowledge level, risk perception, socioeconomic status, media, etc. Besides, level of income and occupation follow them. In the present compilation based on literature, it is aimed to summarize the facts related to GMO. For this reason, the probable risk factors for human health, consumer reaction, the pros and cons of GMOs stated by defining GM generally are explained in the study. With the present study aiming to reveal GM foods and their probable health risks for human, it is concluded that consumers accept the existence of biotechnologic applications but they are not familiar with these products and also consumers have great considerations about GMO produced by genetic modification and they display a negative attitude toward GM products.Consumer should be informed due to all these reasons. Media organs, therefore, have a significant role as the source of information and they will also contribute to raise awareness in society.
\end{abstract}

Keywords: Genetically Modified Foods, Antibiotic Resistance, Allergy, Toxicity, Cancer, Human Health, Consumer Attitude

\section{Introduction}

Biotechnology proceeding with an incomprehensive pace is not only a research area but also it enters our life in many fields ranging from health to nutrition and from our goods to pets. Gene-modified organism (GMO) which is the most publisized product of biotechnology and one of the most popular debates in recent years, continues to be the topical issue of today's world [1]. Any organism that is produced by altering its genetic, material features or by adding some new features via biotechnological techniques is called genetically modified organism (GMO). Today, both pros and cons or health risks of GMOs have started to be argued [2,3]. As there is no certain information about the results of using these products, this situation leads to some questions and disscussions focusing on human being, animal, environment and biological diversity. Undoubtedly that the most significant issue about GMOs is the effects of these foods on human health [4]. Food which is closely connected 
with human health and the most significant factor in terms of adequate and balanced nutrition of world population should be of good quality, abundant, cheap and healthy [5].

\section{Genetically Modified Foods}

The history of selective breeding, the oldest form of genetic engeneering, dates back to ten thousand years, the times when people were organized as agricultural societies. Naturally, selective breeding intervention was performed among the individuals that are relatives, congener or suitable for gene exchange. Today's technology indicates that we can change genetic material directly with deliberate intervention and that between different kinds we can get hybrids not found in nature [6]. It allows gene transfer amongdifferents kinds of creatures from different worlds which cannot be mixed in nature. A fish gene to a tomato and human genes to a sheep, a pig or to Escherichia coli bacteria which lives in the intestines of all mammals can be transferred [7].

Nowadays, most of the foods consumed is either a genemodified food or a kind of food that includes food components produced by gene modification technology [8]. Genetically modified products are totally identical to their natural samples as of their superior fundamental features such as colour, smell, appearance. All over the world, lots of various products have been regenerated by genetic modification and have obtained patent to be used as humanedible and animal feed from health institutes in many countries. Corn, soya, tomato, potato, rice, wheat are the leading agricultural products derived from GM species. The most popular products are soya, cotton, corn and canola and among these the process is applied mostly to soya. In a study conducted in Turkey, as a consequence of the screening, foodstuffs and local seeds did not contained genetically modified organisms, whereas all imported soy and maize seeds were transgenic [9]. Besides these foods, rice, pumpkin, sunflower, peanut, cassava and papaya are also grown as GM. Studies have still been continuing on banana, raspberry, strawberry, cherry, pineapple, pepper, melon and watermelon. Among grains, only for paddy a gene providing resistance to herbicide is transferred. There hasn't been a transgenic product for crops like wheat or barley which have high economic cost [10]. Another application related to GMOs is improving the nutritional value of crops. In the most known example of this, 4 genes encoding the enzymes for ProvitaminA ( $\beta$-caroten) are isolated from Narcissus pseudonarcissus plant and Erwiniauredovora bacteria and transferred to rice [11]. As the grains of this transgenic rice are bright yellow-green, it is called as "golden rice" [12]. Ingredients obtained from genetically modified plants; oil, flour, pulp, syrup, flavour, pigments etc. are used in many branches of industry. Soyabean is given resistance to herbicide by transferring SPSPS gene which is not affected by glyphosate. This gene is isolated from 'Agrobacterium', common bacteria found in soil. Hence, GM soyabean produce EPSPS in bacterial form [13]. Mice was fed orally on EPSPS protein with an amount thousand times greater than the amount of acute dose given to human beings and no toxicity was observed and also there were no functional disorders caused by protein allergy $[14,15,16]$. The gene, isolated from gram-negative Bacillus thuringiensis (Bt) bacteria and encoding $\mathrm{Bt}$ endotoxin which provides a natural resistance against some pesticides like bioinsectiside, is transferred to corn in order to give resistance to an insect called corn stem borer. When planted, this transgenic corn produces toxin and prevents the insect living on itself $[12,16,17]$.

Genetic modification studies are also conducted on animals. For animals, studies aim especially to give resistance against diseases, to control their growth or to change wool quality and milk component. As a result of these studies, fish is the only animal economically produced [18]. Studies of the genes transfer which increase growth and give resistance against cold weather conditions are stil being conducted on 20 kinds of fish particularly on carp, catfish, salmon, and tilefish [19]. In 1993, milk production is increased in milkcows which are given $\mathrm{rBGH}$ (recombinant bovine growth hormone) approved by US FDA. GM animals can be used for the production of lactose-free milk, low-fat milk, low-fat meat, meat with special protein, special-quality meat and milk [20,21].

Besides herbal and animal products, GMO technology is also used for microorganisms. Genetically modified microorganisms (bacteria, fungi and mold) are used as enzyme and food additives in various productions such as bread, beer, cheese, grapery products etc. in order to obtain aminoacid [12]. In fermented meat, milk and other food industries, lactic acid bacteria is commonly used as starter culture for fermentation of foods such as cheese, yoghurt, kephir, sausage and alike. These cultures give the food typespesific flavour and smell by enabling maturation of the fermented food [22,23]. Probable pros and cons of genetically modified organisms are summarized in Table 1 [24].

Table 1. Probable pros and cons of genetically modified organisms

\begin{tabular}{l|l}
\hline Probable advantages & Probable disadvantages \\
\hline 1. Increase in food production and quality & 1. Changes in food quality \\
$\begin{array}{l}\text { 2. Increase inretention period andorganoleptic quality } \\
\text { 3. Improved nutritional quality and good effects on health. }\end{array}$ & 2. Antibiotic resistant and potentialtoxicity \\
4. Enchancedquality and quantitationof meat, milk and animal. & 4. Possible new viruses and toxins. \\
\begin{tabular}{ll} 
5. Increase in herbal production, vaccination and medication production & 5. Threat to the genetic richness \\
6. Biological resistance against herbicide, disease, stres and viruses. & 6. Concerns aboutsresponse deficiency \\
\hline
\end{tabular}
\end{tabular}




\begin{tabular}{l|l}
\hline Probable advantages & Probable disadvantages \\
\hline 7. Precocity & 7. Unfair competition between organic production and traditional production \\
8. New foods and sowing techniques & 8. Unhealthy animals and animal products \\
9. Better use ofwaste & 9. Lack of compulsary awareness raising of customers in some countries \\
10. Saving ofsoil, water and energy & 10. Designing new developments in favor ofwealthy countries \\
\hline 11. Forming a new bioprocess for forest products & 11. World food production's being domineered by a few big firms \\
\hline
\end{tabular}

\section{Effects of the Genetically Modified Foods on Human Health}

In a report published in 2005, World Health Organization (WHO) stated that GMOs have potential risks for human health and growth and have no history of being consumed as a secure food and also that replacing a new gene to the genome of the food modified can cause undesirable developmental and physiological effects [25]. Despite all their benefits, transgenic products have some risks. As these products have some genes that aren't found in the ones grow in nature, they bring some significant hesitation with them. Foreign genes can create unpredictable changes by both increasing nutritional value of some foods and decreasing the value of some other foods [20].

\subsection{Antibiotic Resistance}

Through gene transfer, some features causing allergy and disease can be carried from other organism and as a consequence, there may be the risk of finding unexpected biochemical products in transgenic products. Antibiotic resistant genes are used as markers during gene transfer. Antibiotic resistance emerges due to the transmission of antibiotic resistant genes to the animal or human systems [26]. If antibiotic resistant genes are transmitted to pathogen microorganisms, this makes it difficult to control any bacterial infections $[27,28]$. The lateral transfer of antibiotic resistance to the bacteria in animal or human systems can cause many health risks [29]. Bovine spongiform encephalopathy (known as mad-cow disease), a topical issue in the USA and many European countries, was occurred in cattle in 1985 and people who consumed the meat contaminated by the brain and spinal cord of infected carcasses got sick after a 10 -year incubation period and died in about two months. It is known that the infectious agent is transmitted to cattle by giving them Scrapie-infected sheep carcass meal rendered in concentrate cattle fattening feed as a cheap protein resource [30]. The water consumed by the animal, the meat and milk of which we benefit from, is medicated regularly by antibiotics [31]. In a report published by World Health Organisation (WHO), it is stated that germs develop immunity to antibiotics as a result of wrong antibiotic use and antibiotics used for humans don't have any effect on health. Moreover, studies have indicated that the antibiotics transmitted to humans kill non-resistant bacteria but cause strong and harmful bacteria to multiply in human body and they also decrease the effect of antibiotics given during an infection [31,32].

\subsection{Allergy}

Allergy parts of donor genes can be transmitted to recepient plant or animal by genetic modification of genetic modification plants. Besides, in lots of genetically modified foods, donor microorganisms which have unknown allergenic potential can be used. Genes and new gene combinations transferred from non-food resources can cause allegic reaction or make the existing allergic reaction worse [33]. Sometimes genetically modified products which can cause health problems canbe mixed into natural products during production period. One of the significiant examples of this is "StarLink" incident in USA.StarLink is the trading name of a genetically modified corn developed by Aventis Crop Science Company. This corn includes Cry9C protein and it is defined as "a potential alergenic" by US Environmental Protection Agency (EPA) so in 1998 EPA stated that StarLink can only be used as animal feed or in industry but it cannot be used as human food [34,35]. According to Ozdogan and Ekmen (2002) soyabean given Brazi-nut gene to enhance nutritional value caused severe allergic reaction and was prohibited in 1994 [36]. Products which have " $2 S$ " gene transferred to soyabean from Brazilnut were recalled from the market as they caused allergy [37]. In their study, Gupta et al. have reported that in cotton farm and factory workers who pick and load cotton producing $\mathrm{Bt}$ toxin, some upper respiratory tract, eye and skin related allergies was observed [38].

\subsection{Toxicity}

Herbal products by genetic modification can form some unexpected mutations and these mutations can develop new and high level toxins in foods [36]. There have also been many research results indicating that toxic materials in transgenic plant residue penetrate into soil and water.It is observed that endotoxins produced by some genes can stay in soil for 33 weeks. Therefore toxins are likely to join in the food chain of other organisms [39].GMOs have insect killer genes with genes transmitted because of terminator technology. As the toxic material is produced continously in the plants with these genes, they are called "pesticideproducing plants" [40]. Cumulating of these toxins in the tissue causes significant risks. The type of a well-known substance named L-tryptophan which was undergone genetic engineering process caused the death of 37 Americans and a 
blood disease (Eosinophilia Myalgia Syndrome "EMS")in 5000 people in 1989 [41]. Studies have shown that fermentation process carried out by Bacillus spp. microorganism modified by recombinant DNA technology [20]. In 1967, a potato defined as Lenapo potato designed with a high level dry-matter rate and used in chips production was released to the market in the US. Two years later this potato was recalled by US Agriculture Ministry as it forms solanine toxin [42]. In laboratory tests, it was determined that the potatoes genetically modified by using a viral promoter Cauliflower Mosaic Virus (CaMv) known with snowdrop flower DNA, are poisonous for mammals. These potatoes whose chemical composition is quite different from natural potatoes damaged the vital organs and immunity system of the mice. The most dangerous part is a gastric viral infection occurred in the mice and there is strong evidence that the reason of the disorder is a viral promoter named CaMy. This promoter is widely used in GMOs [41]. According to Ince et al., (2013), toxicity, allergenicity and antibiotic resistance genes of Cry protein in Bt corn can be laterally transferredto the microflora of human digestive system, which threatens human health [43].

\subsection{Cancer}

It is stated by some researchers that GMOs can directly or indirectly have carcinogenic effects. Especially, herbicide resistant chemicals like bromoxynil and glufonsinate used for cotton, soya, corn and rape are known to directly cause cancer [44].Hormone and hormone-like substances affect human health in a negative way. Stilbene group among synthetic anabolic used for cattle fattening has some carcinogenic effects [45]. Genetically modified bovine growth hormone (rBGH) is injected to cattle in order to enchance milk production. $\mathrm{rBGH}$ causes an increase of insulin-like growth factor (IGF-I) in milk. IGF-I causes both normal and cancer cells to grow. The increase of IGF-I level in blood leads to lymphoma, breast, ovarian and uterine, prostate, colon, lung and pancreatic cancer [46]. When animals consume feed including high levels of Dioxin (naturally found and a side product produced by various industrial process like rendering), dioxin cumulates into fatstoring tissues of animals. Consuming the animal products contaminated by high level dioxin have long term toxic and carcinogenic effects on human [47].

\section{Consumer Attitude toward GM Products and Effective Factors}

Altough uncertanities about GM foods continue, studies have shown that there are many differences among people's information, attitude and behaviour toward this issue in various countries $[48,49]$. When the studies conducted are examined, it can be concluded that the attitude toward genetically modified food is affected by factors such as education and knowledge level, risk perception, socioeconomic status, media, etc. Besides, level of income and occupation follow them. In present compilation, literature related to high-level factors will be emphasized.

Education and knowledge level is observed to be highly effective in thoughts about GM products. In a study by Christopher et al., (2008) 40\% of consumers nation-wide stated that they wouldn't consume GMOs even if they are beneficial to health and environment. Also consumers in England, French, Spain and Italy told that they wouldn't consume any GMO product [50]. In a study conducted abroad, it is observed that consumer attitude twowards GMO is "positive" in US and "negative" in other countries. Contrary to findings in Turkey and other countries, nearly half of the US people support agricultural biotechnologies, regard genetically modified foods as "improved" and also taking the advantages of these products into consideration, they think that widespread use of these products can reduce pesticide use and improve nutrition quality [51,52,53].

In their study conducted in European countries, Pardo et al., (2002) reported that $20 \%$ of the study group stated that they have enough knowledge about GMO and among the countries, Greeks was the lowest knowledgable country with a rate of 5\% while Holland was the highest with a rate of 36\% [54]. Magnusson et al., (2002) in their study conducted among consumers in Switzerland, observed that well-educated, young male participants have a more positive attitude toward GM foods [55]. In a study to determine university students' knowledge level and thoughts about transgenic products (GMO), Temelli and Kurt (2011) have concluded that students don't have enough knowledge about transgenic products and they approach GMO products with caution and they also need to be enlightened about these products [56].

Tekedere et al., (2011) reported that 40(36\%) of the students think that they have enough knowledge about GMO whereas $71(64 \%)$ of them think that their knowledge about GMO is inadequate. This finding is students' own perception and indicates thay they believe they have knowledge about GMO but it doesn't academically mean that their knowledge is adequate [57]. Lan's (2006) studies have shown that Chinese people don't have enough knowledge about GM foods. $73.2 \%$ of the participants stated that GM foods are hormone-injected foods and $72.1 \%$ said that people who eat GM products would have cancer [48].

In a study with 8th grade students, Ozden et al.,(2013) stated that most of the students $(96.25 \%)$ think GMO is harmful. The most repeated student answers to the question, "What are the harmful effects of GMO?" are respectively; hormonal disorder $(n=272)$, damages human body $(n=245)$, sickens us $(n=239)$, prevents body improvement $(n=210)$, causes cancer $(n=191)$, causes allergy $(n=131)$, cause heart problem $(\mathrm{n}=101)$ [58].

In their study, Adana et al., (2014) (research the knowledge and opinions of nursing and midwifery students about genetically modified organisms. $74.3 \%$ of the students think GM products are harmful for human health, $74.9 \%$ think GM products are potential carcinogenic. It is observed that nursing and midwifery students don't have enough 
knowledge about this issue [59].

Cankaya and Iscen (2015) have examined the knowledge level and opinions of prospective science and technology teachers about GMOs. According to the findings of the study, nearly all of the prospective teachers think GMOs are harmful and they have a negative attitude toward using GM products [60].

In a study to determine the knowledge, attitude and behaviour of medicine students toward genetically modified organisms, $71.9 \%$ of participants $(n=308)$ stated that they weren't informed enough about genetically modified foods [61].

In a study conducted to determine mothers' attitude toward genetically modified organisms, it is observed that mothers have a high risk perception against GMOs but a low level of knowledge about them. Most of the mothers (96\%) stated that GM products have harmful effects on human health and $82.6 \%$ of them told that they don't want to use them for child nutrition and they won't buy these products [62].

Risk perception toward GMO technology changes among people. The result of a study by Bilen and Ozel (2012) indicated that most of the students $(87 \%)$ had an awareness regarding genetically modified (GM) products. The results also revealed that students think that GM products have risks. Overall, the students thought that GM products should be used for the benefit of technology and people. Based on the findings from this study, some implications for biotechnology education are made [63].

In Kocak et al.,(2010) studies $56.9 \%$ of the participants stated that genetically modified food production is risky for all living beings in nature. It $1 \mathrm{~s}$ observed that risk perception of research group is high [61]. Ergin et al., (2008) found this value as $65.3 \%$ in their study [64]. In Italy and America, consumers' risk perceptions toward genetically modified foods are quite similar, yet Italian customers are found to be more sensitive against probable risks than Americans are. As they care more about the effects of genetically modified foods on human health, they display a tendency to consume them less [65]. It is found in a study by Lan that risk approach and negative attitude toward GM foods increase by the increase of socioeconomic level of the country. They stated that underdeveloped countries support GMO technology more [48]. Contrary to this, Magnusson et al. reported in their study that Americans or Canadians are more positive toward GMO than European people are (55). In a study with university students, Ozdemir and Duman(2010) have found that for nearly more than half of the participants (about 54\%) GMO use is unfavourable for human health, for $24 \%$ GMOs are damaging for human and environment and for $73 \%$ GMOs are insecure [53].

According to the results of the study by Ozmert and Yaman et al., (2011), consumers don't have enough knowledge about GMO products and their knowledge level increases as their level of education increases. Consumers have a negative attitude toward products of this technology in general [66].

Algan Ozkok's study (2015) about consumer opinions on
GM foods has revealed that most of the women have a negative attitude toward GMOs. $73.2 \%(\mathrm{n}=957)$ of participants think that GM products are hormonal foods, $72.1 \%(n=969)$ think that consumers of GM foods can develop cancer, $71.5 \%$ $(n=962)$ think that GM foods have allergenic effcts on human body and $66.1 \%(n=967)$ think that GM products are toxic for human body [67]. Accordind to the result of the study by Kaya et al., (2010) university students regard genetically modified products as potential risk and they have a negative opinion on production, cunsumption, ecological effects and the use of these roducts but they have a positive opinion on genetic applications [68].

According to their study named Urban Consumer's Attitude toward Genetically Modified Organisms and Food in Turkey, Kaya et al., (2014) stated that the negative perception is due to the considerations related to consumers' health, environment and biological diversity and natural resources. In Turkey, urban consumers think that GM foods which are thought to be unhealthy, carcinogenic and allergenic can cause biological pollution, intoxication, infertility, organ damage and antibiotic resistance when consumed or produced [69].

Another effective factor related to thoughts about GM products is media. Tekedere et al., (2011) reported that $70(63.1 \%)$ of the students stated that they heard GMO term first through Radio/Television. 19(17.1\%) of them stated that they heard about it in classes at school. Acquaintances $(10.8 \%)$, newspapers and magazines $(6.3 \%)$, family $(1.8 \%)$ and internet $(0.9 \%)$ follow them respectively. When radio, television, newspaper, magazine and internet are considered as media, it is revealed that $78(70.3 \%)$ of the participants heard about GMO by means of media [57].

Maekawa and Macer (2004) found by their research that the rate of those who state that they heard genetically modified organism first on TV/radio was $67.8 \%$ and of those who heard it from this survey was $8.4 \%$. In a study on students, Maekawa and Macer observed that concerns and debates about GMO started in 1990s in Japon and that the people heard genetically modified organisms from daily newspapers, television or articles [70].

Huang et al., (2006) in their study, stated that the rate of hearing about GM food is $67 \%$ in China, $77 \%$ in the USA, $77-92 \%$ in European countries. In the study, it is also stated that the reason of the low rate in China can be due to fewer debates on GMO in local media [71].

In a study conducted to determine the knowledge, attitude and behaviour of women living in housing estate toward genetically modified organism, it is observed that most of the participants $(91.9 \%)$ gained their knowledge from TV, newspaper, magazine etc. This situation can be caused by the fact that GMO have become more popular lately and participants follow the media closely [67]. Kocak et al., (2010) reported in their study that the rate of participants who heard about genetically modified organism first through Radio/TV is $67.8 \%$ and of those who heard it from this survey was $8.4 \%[61]$. In a study conducted with pre-school staff, it is detected that the knoeledge about hormone, 
additives and genetically modified foods is limited and gathered from TV. The reason why the knowledge levels are different is that the source of information is mostly media, internet or environment.

In the study by Lu (2006), Chinese people's lack of information about GM foods is found to be the result of limited broadcasting or publishing in media [72]. In the study, it is also stated that the students heard GMO term first from media although they don't prefer media as a source of education. Therefore useful strategies should be developed to use effectively the power of media providing informal knowledge. Among them, distance education, video conference, education with TV are some options. This power of media can be benefited for GMO issue to develop social consciousness.

\section{Conclusion}

Among the hesitations about GMO widely used and consumed all over the world, the most topical issue is the probable health risks caused by GMOs which are consumed as food. While genetically modified foods continue to emerge, debates about the effects of them on environment and health become a growing problem. Generally, experts of the issue support studies to continue but consumers react against them as they don't have enough knowledge. In this respect, GM products should be released to the market after enough scientific studies are conducted and should be checked in legal framework and also consumers should be informed about the issue. By this study aiming to reveal the probable risks of genetically modified foods for human health, it is observed that consumers accept the existence of biotechnologic applications but they are not familiar enough with these products. Also the study indicated that consumers have great considerations about GMO produced by genetic modification and they display a negative attitude toward GM products. GMO technologies have the danger of causing harmful and unpredictable adverse effects that cannot be reversed or rectified. Consumer should be informed due to all these reasons. Media organs, therefore, have a significant role as the source of information and they will also contribute to raise awareness in society.

\section{References}

[1] Anonymous "Biyoguvenlik Kanunu," 26 Mart 2010tarihli Resmi Gazete, 2010, Sayi: 27533, Turkey. http://www.resmiga zete.gov.tr/eskiler/2010/03/201003267.htm

[2] DPT. VIII. Bes Yillik Kalkinma Plani, Biyoteknolojive Biyoguvenlik Ozel Ihtisas Komisyonu Raporu, Ulusal Molekuler Biyoloji, Modern Biyoteknolojive Biyoguvenlik Atilim Projesi Onerisi, 2000, Ankara, Turkey.

[3] Anonymous "Biyoguvenlik Kuru 1Kararlari," 26 Ocak 2011 tarihli Resmi Gazete. 2011a, Sayi: 2782, Turkey. http://www.resmigazete.gov.tr/eskiler/2011/01/201101269.htm
[4] B. Karli, A. Bilgic, S. Celik, "Applying of more than one twostage limited dependant variables on microeconomics fields: Cunsumption Sample of Genetically Modified Foods in Turkey," 10th Econometrics and Statistics Symposium, 2009, Erzurum, Turkey.

[5] M. Arda, "Biotechnology (Some basic principles)," KUKEM Association Scientific Publications: 2, 1994, Ankara. 349. (GDO2), Turkey.

[6] M. Akcelik, "Genetically Modified Organisms and the Use in Foods," TMMOB Food Engineers Room Books Series, 2, 2003, Ankara, Turkey.

[7] W.M. Ho, "Is it Genetic Engineering, Nightmare or Dream?"First edition, Turkey Is Bank Cultural Publications, interpreter: Cakmak, E., 1999, s. 37, Istanbul, Turkey.

[8] O. Gursoy, G. Kavas, O. Kinik, "Genetically modified products and dairy products," Turkish Agriculture, MarchApril, 2003, Sayi: 150.ISSN:1303-2364, pp. 20-24. Ministry of Agriculture and Rural Affairs, Ankara, Turkey.

[9] A. Turhan, S. Kafkas, "Detection of Genetically Modified Soybean and Maize," C.U Journal of Science and Engineering, 2013, vol. 29-2.

[10] O. Cicekci, "Determining the knowledge and the opinions about the transgenic products (gmo) of the teacers in primary school," unpublished Postgraduate Thesis, Gazi University Institute of Educational Sciences 2008, Ankara, Turkey.

[11] A. YXS Al-Babili, J. Kloti, P. Zhang, P. Lucca, I. Beyer, Potrykus, "Engineering the provitamin a (beta karoten) biosynthetic pathway into (carotenoid-free) rice endosperm," Science, vol. 287, 2000, pp. 303-305.

[12] V. Celik, D.T. Balik, "Genetically modified organisms (GMO)," Journal of the Institute of Science and Technology of Erciyes, 2007, 23 (1-2): 13-23.

[13] S. Kacan, "Genetic modification," Http://www.Geocities.com/sultanhisar2000/taris./temmuzagustos 2000.

[14] Z. Zhang, A. Xing, P. Staswick, E.T. Clemente, "The use of glufosinate as a selective agent in agrobacterium-mediated transformation of soybean," Plant Cell, Tissue, Organ Culture, vol. 56, 1999, pp. 37-46.

[15] K.T. Atherton, "Safety Assessment of Genetically Modified Crops", Toxicology, 2002, 181-182, 421-426.

[16] A. Demir, F. Seyis, O. Kurt, "Genetically modified organisms: I. Plants,” J. of Fac. of Agric., OMU, 2006, 21(2): 249-260.

[17] A.M. Shelton, J.D. Tang, R.T. Roush, T.D. Metz, E.D. Earle, "Field tests on managingresistence to Bt-engineered plants," Nat Biotechnol, vol. 18, 2000, pp. 339-342.

[18] D. Sarikaya, "Genetically modified organisms and biosafety," http://www.izmircevre.Gov.tr/yayinayrinti.Asp?Div=190\&did $=: 25 . / 2003$.

[19] M. Querci, M. Van Den Bulcke, J. Zel, G. Van Den Eede, H. Broll, "New approaches in GMO detection," Anal BioanalChem., 2010, 396, 1991-2002.

[20] S.G. Uzogara, "The Impact of genetic modification of human foods in the 21st Century: A Review," Biotechnol Adv., vol.18, 2000, pp. 179-206. 
[21] S. Leimanis, M. Hernández, S. Fernández, F. Boyer, M. Burns, S. Bruderer, T. Glouden, N. Harris, O. Kaeppeli, P. Philipp, M Pla, P. Puigdomènech, M. Vaitilingom, Y. Bertheau, J. Remacle, "A microarray-based detection system for genetically modified (GM) food ingredients," Plant MolBiol, 2006, 61 (1): 123-139.

[22] F.E. Ahmed, Detection of GMO in foods. Trends in Biotechnology, 2002, 20 (5): 215-223.

[23] W. Sybesma, J. Hugenholtz, W.M. De Vos, E.J. Smid, "Safe use of genetically modified lactic acid bacteria in food. Bridging the Gap between consumers, green groups and industry," Electronic Journal of Biotechnology, 2006, 9 (4): 424-448.

[24] Biogeves, "Determining GMO in Seeds and DNA-Protein Analysis Course," 2009, Fransa.

[25] F. Cellini, A. Chesson, L. Colquhoun, A. Constable, H.V. Davies,K.H. Engel, A.M.R. Gatehouse, S. Karenlampi, E.J. Kok,J.J. Leguay, S. Lehesranta, H.P.J.M. Noteborn,J. Pedersen,M. Smith, "Unintended effects and their detection in genetically modified crops," Food and Chemical Toxicology, 2004, 42, 1089-1125.

[26] S. Kefi, "Genetically Modified Organisms and the Use in Foods," TMMOB Food Engineers Room Books Series, 2, 2003, Ankara, Turkey.

[27] S. Yanaz, "The subject of genetically modified organisms and the Cartagena Biosafety Protocol," Foreign Trade Magazine, vol. 28, 2003, pp. 116-126.

[28] A. Gucukoglu, O. Kuplulu, "Genetically Modified Foods," Journal of Veterinary Medical Association, 2006, 77 (2): 3038.

[29] I.K. Vasil, "Biotechnology and food security for 21st century: A real-world Perspective," Nat Biotechnol, vol. 16, 1998, pp.399-400.

[30] H. Yilmaz, Mad cow disease, animal products and human health,Http://www.cinetarim.com.tr/dergi/arsiv32/delidana.ht m, 2000/ Access to Date: 12.12.2003.

[31] O.Ersahin, "What is ecological agriculture?".Http://www.alternatifenerji.com/info_articles01 _09.html/2002)Access to Date: 02.05.2003.

[32] Anonymous "Ecological (organic, biyological) in agriculture," 2002, Http://www.setbir.org.tr/makale.htm / Access to Date: 02.05.2003.

[33] M. Baran, "Genetically modified organisms and biosecurity systems," Turkish Agriculture, 2003, March-April, pp.12-15.

[34] R. Batista, B. Carmo, M. Cardoso, C. José, H.S. De Almeida, A.B. Manique, A. Bento, L. Ricardo, C.P. M.M. Oliveira, "Lack of Detectable allergenicity of transgenic maize and soya samples," J Allergy ClinImmunol, 2005, 116 (2): 403410.

[35] P.J. Vergragt, H.S. Brown, "Genetic engineering in agriculture: New approaches for risk management through sustainability reporting," Technological Forecasting \& Social Change, vol. 75, 2008, 783-798.

[36] S.Ozdogan, Z.I. Ekmen, "What is genetic engineering?" Http://www.yunus.hacettepe.edu.tr/aacorner/GEN/02/genetik. $\mathrm{htm} / 2002$, Access to Date: 20.12.2002.
[37] N. Batalion, "50 Harmful Effects of Genetically Modified Foods," Americans for Safe Food, 2000, Oneonta, NY.

[38] A. Gupta, A. Mandloi, A. Nidhi, "Impact of Bt Cotton on Farmers' Health (in Barwani and Dhar District of Madhya Pradesh)," Investigation Report, 2005, 13-16.

[39] H. Tapp, G. Stotzky, "Persistence of the insecticidal toxins from bacillus thurigiensissusp, kurstaki in soil," Soil Biol. Biochem., vol. 30, 1998, pp. 471-476.

[40] R.L. Philips, S.A. Eberhart, "Novel Methodology in Plant Breeding. In Proc," Of the Int Crop Sci Cong Ames, USA. Crop SciSoc of America, 1993, pp. 647-648.

[41] K. Raja, "Watch dog refuses claims of rapidglobal growth in ge crops",http://www.twnside.org.sg/title/5266c.htm/2003, Access to Date: 19.10.2011.

[42] I. Erol, "Food hygiene and Microbiology," Pozitif Matbaacilik ISBN: 978-975-00131-0-9, 2007, pp. 331-341, Ankara, Turkey.

[43] H.O. Ince, C. Bahadiroglu, S. Toroglu, H. Bozdogan, "The Assessments on Resistance of Genetically Modified Corn against Some Insect Species," Nevsehir Haci Bektas Veli University J. Inst. Sci. \& Tech.2013, Cilt 2(1): 78-89.

[44] I. Haspolat, "Genetically modified organisms and biosecurity," Veterinary journal of Ankara Univ Vet FakDerg, 2012, 59, 7580 .

[45] Y. Sayan, M. Polat, "Ecological (organic, biological) in agriculture livestock," Turkey, 2. Ecological Farming Symposium, Narenciyeve Seracilik Arastirma Enstitusu, Antalya, 2001, pp. 95-105.

[46] Anonymous "The effect on cancer risks of genetically modified milk and milk products," 2011b, Http://www.forum.gidagundemi.com/ Access to Date: 14.02.2011.

[47] G. Aydin, "Dioxin in feed safety," Journal of Turkish Feed .manufacturers' Association Feed Magazin, 2000, issue: 26: 55 , Turkey.

[48] L. Lan, "Chinese public understanding of the use of agricultural biotechnology," a case study from Zhejiang Province of China," Lu / J Zhejiang Univ Science B, 2006, 7: 257-266.

[49] J. Februhartanty, T.N. Widyastuti, D.N. Iswarawanti, "Attitudes of agricultural scientists in indonesia towards genetically modified foods," Asia Pac J ClinNutr, 2007, 16: 375-380.

[50] I. Christoph, M. Bruhn, J. Roosen, "Knowledge, attitudes towards and acceptability of genetic modification in Germany," Appetite, 2008, 51; 58-68.

[51] J.W. Heffernan, V.N. Hillers, "Attitudes of consumers living in Washington regarding food biotechnology," Journal of American Dietetic Association, 2002, 102 (1): 85-89.

[52] W.S. Chern, K.A. Rickertsen, "Comparative Analysis of Consumer Acceptance of GM Foods in Norway and the USA. In Consumer Acceptance of Genetically Modified Foods," Edited by R.E. Evenson and V. Santaniello, Cabi Publishing, 2004, Cambrige, USA.

[53] O. Ozdemir, M. Duran, "Consumer Attitude towards Biotechnological Applications and Genetically Modified 
Organisms," Academic Food Journal, 2010, 8 (5): 20-28.

[54] R. Pardo, C .Midden, JD. Miller, "Attitudes toward biotechnology in the European Union," J Biotechnol 2002; 98: 9-24.

[55] MK. Magnusson, UKK, Hursti. "Consumer attitudes towards genetically modified foods," Appetite 2002; 39: 9-24.

[56] A. Temelli, M. Kurt, "Determination of Information and Opinion of University Students about Transgenic Products (GMO)," Theoretical Pedagogy, 2011, 4 (2): 247-261.

[57] H. Tekedere , B. Taban, M. Caliskan, H. Demirtola, "Health Services Vocational School of genetically modified organisms analysis of relevant training requirements with students," Journal of Turkish Science Education September, 2011, Issue 3 , volume 8 .

[58] M. Ozden, A. Akgun, A. Cinici, H. Gulmez, F. Demirtas, "Investigation of 8th Grade Student's Knowledge of Genetically Modified Organism (GMO) and their Attitudes toward Biotechnology," Adiyaman Univ. J. Sci. \& Tech. 2013, 3 (2): 94-115.

[59] F. Adana, N. Gezer, S. Ogut, "Knowledge and opinions of the health school students about genetically modified organisms (GMOS)," AcibademUniv.Journal of Health Sciences, 2014,vol.5, Number: 4.

[60] C. Cankaya, C. FilikIscen, "Determining the knowledge and the opinions about the genetically modified organisms (gmo) of pre-service science teachers," International Journal of Social Science.

Doinumber:http://dx.doi.org/10.9761/JASSS2714 Number: 32, p. 537-554, Winter III 2015.

[61] N. Kocak, T. Turker, S. Kilic, et. all. "Assessment of knowledge, attitude and behavior level of medical school students about genetically modified organisms," Gulhane Med J. 2010, 52(3): 198-204.

[62] S. Ozturk, S. AgapinarSahin, Guducu, F. Tufekci, "The level of knowledge and attitudes of mothers to genetically modified organisms," Izmir Dr. Behcet Uz Journal of Children's Diseases, 2014, 4 (2): 117-122. Doi: 10.5222/buchd.2014.117.
[63] K. Bilen, M. Ozel, "Gifted students' knowledge of and attitudes toward biotechnology," Necatibey Faculty of Education Electronic Journal of Science and Mathematics Education vol. 6, Issue 2, December 2012, 6 ( 2): 135-152.

[64] I. Ergin, TS. Gursoy, AZ. Ocek, M. Cicekoglu, "Genetically modified organisms, the Health Vocational School students on the knowledge, attitude and behavior," TAF Preventive Medicine Bulletin, 2008, 7(6): 503-508.

[65] V. Moses, "Biotechnology products and European consumers," Biotechnology Advances 1999; 17: 647-678.

[66] S. Ozmert, H. Yaman, "Assessment of consumer's attitudes and knowledge levels towards genetically modified foods," Kocatepe Veterinary Journal, 2011, 4 (1): 31-41.

[67] G. Algan Ozkok, "Consumer attitudes towards consumption of genetically modified products," DBHAD International Peer-Reviewed Journal of Nutrition Research April 2015 Issue: 03 Volume: 02 Winter Spring. Doi: 10.17362/DBHAD.2015310319.

[68] E. Kaya, H. Gurbuz, M. Derman, “Assessment of knowledge, attitude and behavior level of medical school students about genetically modified organisms," Gulhane Med J. 2010, 52(3): 198-204.

[69] I.H Kaya, N. Konar, N. Artik, "Urban Consumer's Attitudes toward Genetically Modified Organisms and Foods in Turkey," Journal of Agricultural Sciences, 2014, 20: 71-82.

[70] Maekawa F, Macer D. "How Japanese students reason about agricultural biotechnology," SciEng Ethics 2004; 10: 705-716.

[71] Huang J, Qiu H, Bai J, Pray C. “Awareness, acceptance of and willingness to buy genetically modified foods in Urban China", Appetite 2006, 46: 144-151.

[72] L. Lü, "Chinese public understanding of the use of agricultural biotechnology: a case study from Zhejiang Province of China," Journal of Zhejiang University Science B, 2006, 7(4): 257-266. 